\title{
Regulation of hepatic haem metabolism
}

\section{Disparate mechanisms of induction of haem oxygenase by drugs and metals}

\author{
Beth C. LINCOLN, $\dagger$ John F. HEALEY $\dagger$ and Herbert L. BONKOVSKY* $\ddagger$ \\ Departments of *Biochemistry and $†$ Medicine and the $\ddagger$ Clinical Research Center, Emory University School of Medicine, \\ Atlanta, GA 30322, U.S.A.
}

\begin{abstract}
We studied drug- and metal-mediated increases in activity of haem oxygenase, the rate-controlling enzyme for haem breakdown, in chick-embryo hepatocytes in ovo and in prin :y culture. Phenobarbitone and phenobarbitone-like drugs (glutethimide, mephenytoin), which are known to increase concentrations of an isoform of cytochrome $P-450$ in chick-embryo hepatocytes, were found to increase activities of haem oxygenase as well. In contrast, 20-methylcholanthrene, which increases the concentration of a different isoform of cytochrome $P-450$, had no effect on activity of haem oxygenase. Inhibitors of haem synthesis, 4,6dioxoheptanoic acid or desferrioxamine, prevented drug-mediated induction of both cytochrome $P-450$ and haem oxygenase in embryo hepatocytes in ovo or in culture. Addition of haem restored induction of both enzymes. These results are interpreted to indicate that phenobarbitone and its congeners induce haem oxygenase by increasing hepatic haem formation. In contrast, increases in haem oxygenase activity by metals such as cobalt, cadmium and iron were not dependent on increased haem synthesis and were not inhibited by 4,6-dioxoheptanoic acid. We conclude that (1) induction of hepatic haem oxygenase activity by phenobarbitone-type drugs is due to increased haem formation, and (2) induction of haem oxygenase by drugs and metals occurs by different mechanisms.
\end{abstract}

\section{INTRODUCTION}

It is now widely accepted that a major factor in the regulation of hepatic haem metabolism is the size of a small 'regulatory' haem pool (Granick et al., 1975; Bonkovsky, 1982). Evidence for the existence of such a regulatory haem pool, although still indirect, is compelling. A deficiency of haem in this pool is thought to lead to a de-repression of the first and rate-controlling enzyme of haem synthesis, namely 5-aminolaevulinate (ALA) synthase (EC 2.3.1.37). In contrast, an excess of haem provided by the parenteral administration of haem to animals leads to a decrease in ALA synthase and an increase in activity and induction of haem oxygenase (EC 1.14.88.3) (Bonkovsky, 1982; Kikuchi \& Yoshida, 1983). In addition, the degree of haem saturation of the enzyme tryptophan dioxygenase (EC 1.13.11.11), a cytoplasmic soluble enzyme that binds haem with a relatively low avidity, has been proposed to reflect the relative size of the hepatocyte regulatory haem pool (Badawy \& Evans, 1975; Badawy \& Morgan, 1980; Morgan \& Badawy, 1980; Sardana \& Drummond, 1985), although more recent studies in rats have suggested that tryptophan dioxygenase in intact hepatocytes is always completely saturated with respect to haem (Salter \& Pogson, 1986).

The family of haemoproteins collectively called 'cytochrome $P-450$ ' is the major user of haem synthesized by hepatocytes (for reviews, see Sato \& Omura, 1978; Bonkovsky, 1982). Several isoforms of cytochrome $P$ 450 are known to be inducible by a variety of drugs and chemicals, including phenobarbitone and 20-methylcholanthrene (Sato \& Omura, 1978). In several studies, an inverse relationship has been observed between concentrations of hepatic cytochrome $P-450$ and haem oxygenase, particularly when haem oxygenase was increased in activity by administration of a variety of metals (Maines \& Kappas, 1974, 1977; Sardana et al., 1980; Kikuchi \& Yoshida, 1983; Yoshida et al., 1984). It has been pointed out that there is not an obligatory inverse relationship between concentrations of cytochrome $P-450$ and activities of haem oxygenase (Paine \& Legg, 1978; Drummond et al., 1982; Kikuchi \& Yoshida, 1983). Administration to rats of chemicals capable of increasing the concentration of cytochrome $P-450$, such as phenobarbitone or 20-methylcholanthrene, was found not to affect activity of hepatic haem oxygenase (Schacter \& Mason, 1974), although a modest increase in both enzymes was described in rats treated with toxic doses of benzene (Abraham et al., 1986).

In previous studies, we and others demonstrated that chick-embryo hepatocytes, in ovo or in primary cell culture, provide a useful experimental system for study of the regulation of hepatic haem metabolism. In particular, chick-embryo hepatocyte cultures retain normal inducibility of ALA synthase (Granick et al., 1975), at least two isoforms of cytochrome $P-450$ (Sinclair et al., 1986) and haem oxygenase (Maines \& Sinclair, 1977; Sardana et al., 1982).

In the studies reported here, we used chick-embryo hepatocytes in ovo and in cell culture to elucidate further the mechanisms underlying the regulation of hepatic haem metabolism, particularly the induction of haem oxygenase. Our results show that phenobarbitone-like drugs, exemplified by glutethimide and mephenytoin, are inducers of haem oxygenase, as well as of the same isoform of cytochrome P-450 (Sinclair et al., 1986). Results with inhibitors of haem synthesis show that the 
induction of haem oxygenase and cytochrome $P-450$ by mephenytoin is dependent on an increase in haem formation. Induction of haem oxygenase by heavy metals also occurs in chick-embryo hepatocytes in ovo or in culture, but this induction, unlike that produced by drugs, is not mediated by haem. A portion of this work has appeared in abstract form (Lincoln et al., 1986) and was presented at the annual meeting of the American Society of Biological Chemists in June 1986.

\section{METHODS}

\section{Materials}

Fertilized White Leghorn chicken eggs were from Haley Farms, Canton, GA, U.S.A. Haemin, albumin, NADPH, insulin, tri-iodothyronine, cycloheximide, glutethimide, 20-methylcholanthrene, DNAase, dexamethasone and 4,6-dioxoheptanoic acid were from Sigma, St. Louis, MO, U.S.A. Williams E medium, trypsin and antibiotics were from Gibco, Grand Island, NY, U.S.A. Porphyrins were from Porphyrin Products, Logan, UT, U.S.A. Desferrioxamine was from Ciba-Geigy, obtained through the pharmacy at Emory University Hospital. Mephenytoin was a gift from Sandoz, East Hanover, NJ, U.S.A. [U- ${ }^{14}$ C]Leucine was from New England Nuclear, Boston, MA, U.S.A. Other chemicals were reagent grade from Sigma, or Fisher, Phillipsburg, NJ, U.S.A.

\section{Embryo treatments and sample preparation}

Glutethimide and mephenytoin were injected into the egg sac in $0.2 \mathrm{ml}$ of dimethyl sulphoxide. Livers from 17-18-day chick embryos were homogenized $(20 \%$,

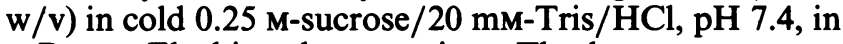
a Potter-Elvehjem homogenizer. The homogenate was centrifuged for $10 \mathrm{~min}$ at $10000 \mathrm{~g}$ at $4^{\circ} \mathrm{C}$. The resulting supernatant was centrifuged at $105000 \mathrm{~g}$ for $1 \mathrm{~h}$ at $4^{\circ} \mathrm{C}$; the final microsomal pellet was washed and resuspended in $0.1 \mathrm{M}$-potassium phosphate $/ 20 \%(\mathrm{v} / \mathrm{v})$ glycerol/ $1 \mathrm{mM}-\mathrm{Na}_{4}$ EDTA, pH 7.4.

\section{Cell culture}

Cell cultures from 16-18-day chick-embryo livers were prepared by digestion with trypsin and DNAase, and maintained in a serum-free medium in the presence of insulin $(0.17 \mu \mathrm{M}$, for first $24 \mathrm{~h}$ only), tri-iodothyronine $(1.5 \mu \mathrm{M})$ and dexamethasone $(0.76 \mu \mathrm{M})$ (Sinclair et al., 1979). Any additions were made in dimethyl sulphoxide ( $1 \mu \mathrm{l} / \mathrm{ml}$ of medium). Controls received dimethyl sulphoxide only. Cells were rinsed, scraped into buffer with a rubber spatula and then homogenized in $0.1 \mathrm{M}$ potassium phosphate $/ 20 \%$ glycerol $/ 1 \mathrm{mM}-\mathrm{Na}_{4}$ EDTA, pH 7.4.

\section{Assays}

Cytochrome $P-450$ was measured in microsomal fractions from embryo livers, or in $8700 \mathrm{~g}$ supernatant of Lubrol-solubilized cell homogenate (Sinclair et al., 1979), by the method of Omura \& Sato (1964).

Haem oxygenase was measured by a modification of the method of Tenhunen et al. (1969). The rate of bilirubin formation at $37^{\circ} \mathrm{C}$ was assessed by the increase in absorbance at $470 \mathrm{~nm}$ versus $540 \mathrm{~nm}$. In addition to the sample, the $1.0 \mathrm{ml}$ reaction mixture contained $0.085 \mathrm{M}$ potassium phosphate, pH 7.4, $5 \mathrm{mm-desferrioxamine,}$ $42 \mu \mathrm{M}$-haemin and $25 \mu \mathrm{M}$-bovine serum albumin added as a haem-albumin solution, biliverdin reductase $(0.05 \mathrm{ml}$
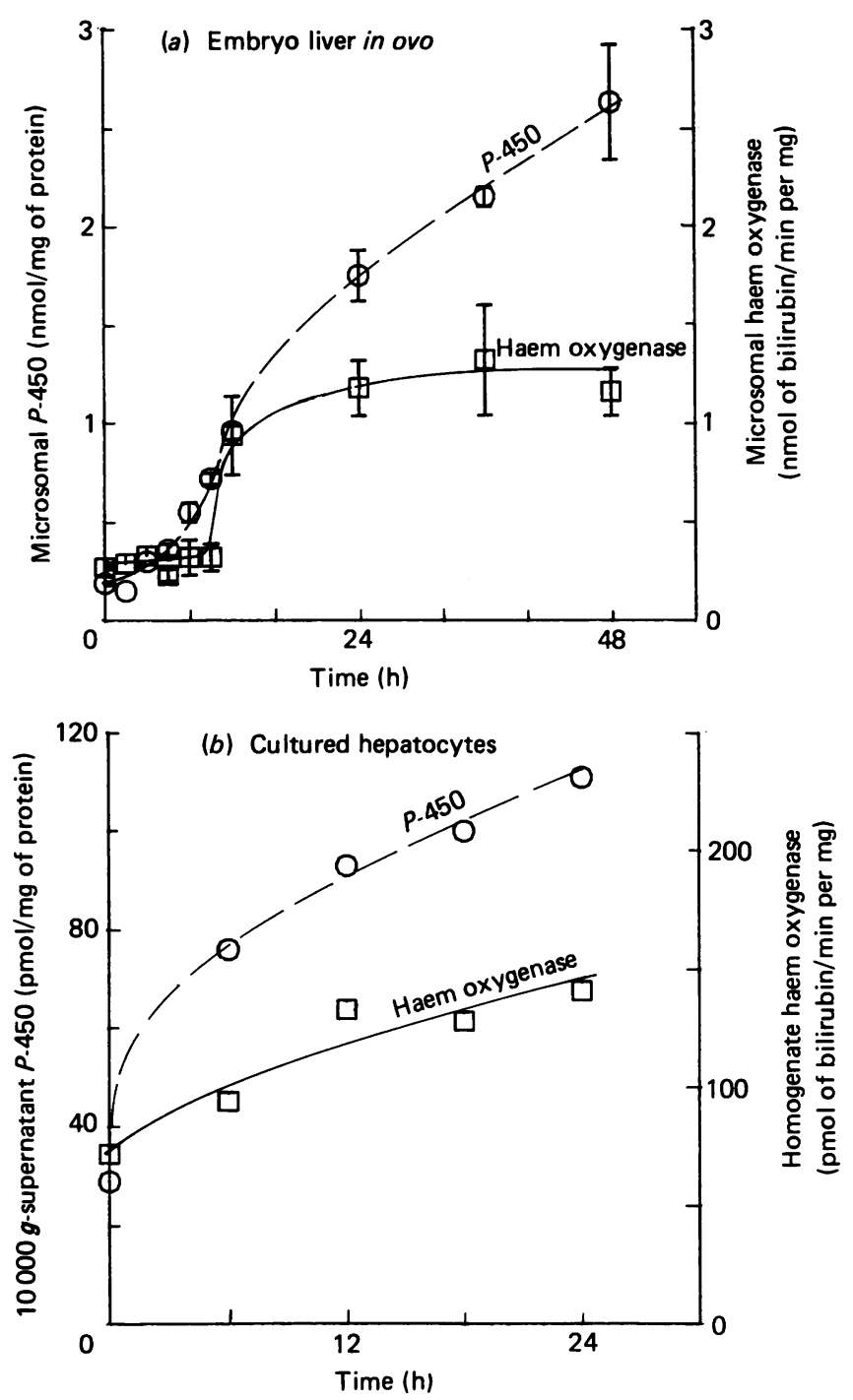

Fig. 1. Time course of effect of glutethimide on haem oxygenase $(\square)$ and cytochrome $P-450$ (O) in (a) intact chickembryo liver and (b) cultured chick-embryo hepatocytes

(a) Embryos were injected with glutethimide $(6 \mathrm{mg} / \mathrm{egg})$. Each point represents the mean \pm S.E.M. $(n=3-5)$. (b) Cultured hepatocytes were exposed to $50 \mu \mathrm{M}$-glutethimide. Each point represents the average of two plates, whose individual values differed by less than $10 \%$ from the mean.

of a $105000 \mathrm{~g}$ supernatant of a $20 \%$ homogenate of perfused rat liver), and $1 \mathrm{~mm}-\mathrm{NADPH}$ (all final concns.). The absorption coefficient for bilirubin obtained with standards was $66 \mathrm{~mm}^{-1} \cdot \mathrm{cm}^{-1}$. The reaction mixture with samples from cell cultures contained $0.1-0.2 \mathrm{mg}$ of homogenate protein, and those from embryo livers contained $0.05-0.4 \mathrm{mg}$ of microsomal protein.

Porphyrins were determined by the method of Grandchamp et al. (1980). Homogenates of embryo livers were diluted with 4 vol. of a mixture of $70 \%(w / v) ~ \mathrm{HClO}_{4} /$ water/methanol (1:10:10, by vol.), with further dilutions as necessary. Cell homogenates in medium were diluted with an equal volume of $\mathrm{HClO}_{4} /$ methanol $(1: 9, \mathrm{v} / \mathrm{v})$. The porphyrin patterns in some samples were verified by h.p.l.c. (Bonkovsky et al, 1986).

The rate of protein synthesis in cultured hepatocytes 

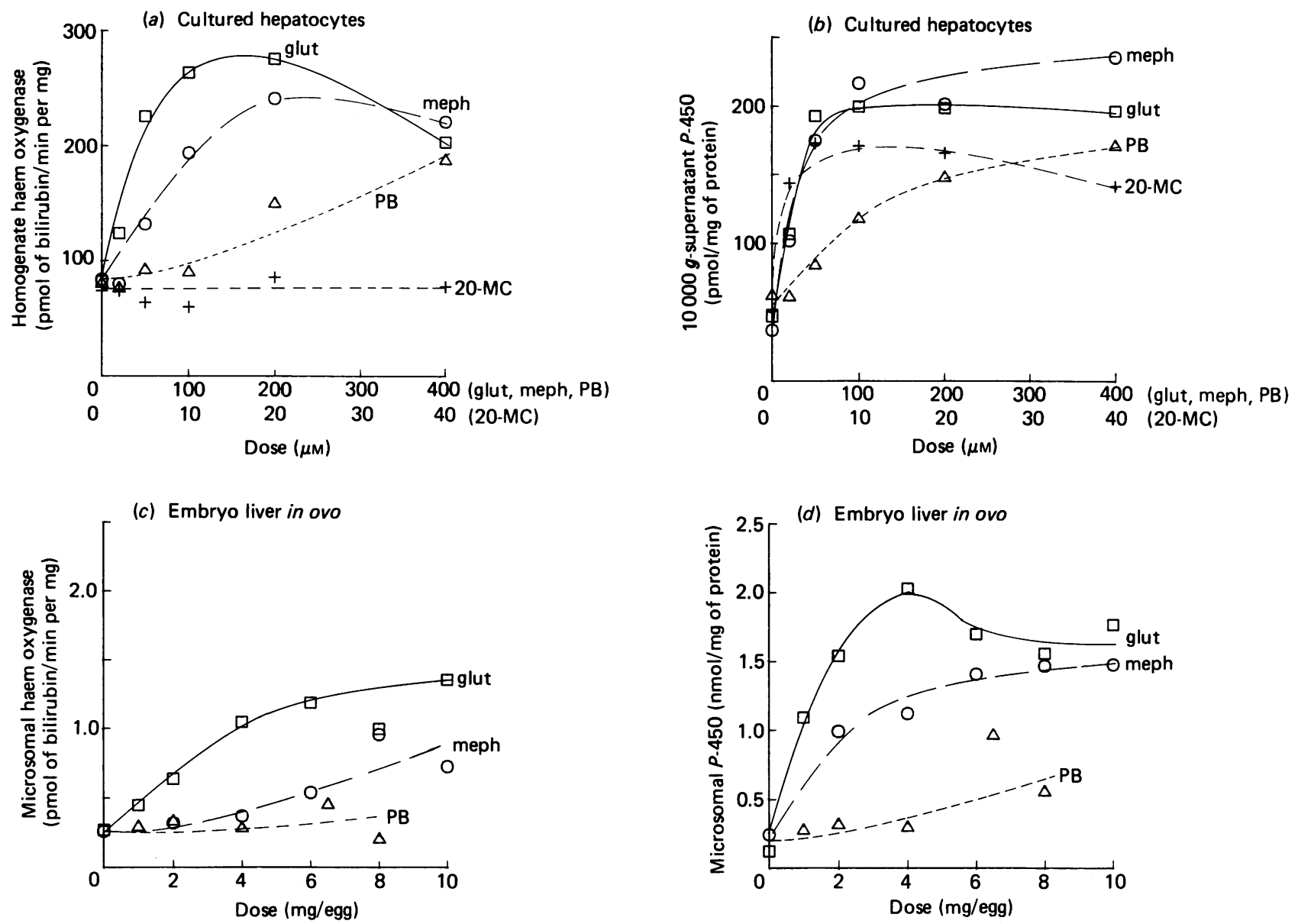

Fig. 2. Dose-response of haem oxygenase $(a, c)$ and cytochrome $P-450(b, d)$ to glutethimide, mephenytoin, phenobarbitone and 20-methylcholanthrene in intact chick-embryo liver $(a, b)$ and in cultured chick-embryo hepatocytes $(c, d)$

(a), (b), Representative experiment of a $24 \mathrm{~h}$ exposure of cultured chick hepatocytes to drugs. Each point represents a single plate. $(c),(d), 24 \mathrm{~h}$ exposure of chick embryos to drugs. Each point represents the average of several experiments: for glutethimide (glut) $n=3-4$; phenobarbitone (PB) $n=2$; mephenytoin (meph) $n=4 ; 20$-methylcholanthrene (20-MC) $n=4$.

was estimated by the incorporation of $\left[\mathrm{U}-{ }^{14} \mathrm{C}\right]$ leucine $(344 \mu \mathrm{Ci} / \mu \mathrm{mol} ; 0.05 \mu \mathrm{Ci} / 3.5 \mathrm{~cm}$ plate) into protein over $2 \mathrm{~h}$. After the $2 \mathrm{~h}$ exposure, the cells were rinsed with $0.15 \mathrm{M}-\mathrm{NaCl}$, and the protein was precipitated with $5 \%$ $(\mathrm{w} / \mathrm{v})$ trichloroacetic acid. The protein precipitate was rinsed with $0.15 \mathrm{M}-\mathrm{NaCl}$ and scraped into $0.1 \mathrm{M}-\mathrm{NaOH}$ / $0.1 \%(\mathrm{w} / \mathrm{v})$ deoxycholate; portions were used for measurement of radioactivity and protein concentration.

\section{Ouchterlony analysis}

Rabbit antiserum was produced against a form of cytochrome $P-450$ purified from glutethimide-induced chick-embryo livers (Sinclair et al., 1986). The Ouchterlony double diffusion followed the method of Thomas et al. (1976).

\section{Other methods}

Proteins were measured by the method of Lowry $e t$ al. (1951), with bovine serum albumin as a standard.

Experiments were repeated two to four times; unless otherwise noted, representative data from a single experiment are presented in the Figures.

\section{RESULTS}

Glutethimide increased both cytochrome $P-450$ and haem oxygenase in embryo liver in ovo and in cultured chick-embryo hepatocytes (Fig. 1). In embryo liver in ovo (Fig. 1a), concentrations of cytochrome $P-450$ rose within $4 \mathrm{~h}$ after the drug was administered, and continued to rise throughout the $48 \mathrm{~h}$ induction period, reaching values greater than 10 -fold above controls. In contrast, the activity of haem oxygenase remained at control values for $10 \mathrm{~h}$ and then increased rapidly to maximal values about 5-fold above control. In cultured hepatocytes exposed to $50 \mu \mathrm{M}$-glutethimide (Fig. $1 b$ ), concentrations of cytochrome $P-450$ rose throughout the $24 \mathrm{~h}$ induction period, despite an increase in haem oxygenase activity. The activity of haem oxygenase was significantly increased $(P<0.05)$ by $12 \mathrm{~h}$. Measurements of concentrations of cytochrome $P-450$ and haem oxygenase activity in embryo liver in ovo were with microsomal fractions, and those in cultured hepatocytes were with homogenate, which accounts for the apparent difference in absolute values.

Other inducers of cytochrome $P-450$ also increased haem oxygenase in cultured hepatocytes (Fig. 2a). 
Table 1. Effects of chemicals on porphyrin accumulation by chick-embryo hepatocytes

Embryo or cultured hepatocytes were treated as shown for $24 \mathrm{~h}$. Values represent means \pm S.D.; *significantly different from control $(P<0.05)$.

\begin{tabular}{|c|c|c|c|c|c|}
\hline $\begin{array}{l}\text { Hepato- } \\
\text { cytes }\end{array}$ & Treatment & $\begin{array}{l}\text { Uroporphyrin } \\
\text { (pmol/mg of } \\
\text { protein) }\end{array}$ & $\begin{array}{l}\text { Coproporphyrin } \\
\text { (pmol/mg of } \\
\text { protein) }\end{array}$ & $\begin{array}{l}\text { Protoporphyrin } \\
\text { (pmol/mg of } \\
\text { protein) }\end{array}$ & $\begin{array}{l}\text { Total porphyrin } \\
\text { (pmol/mg of } \\
\text { protein) }\end{array}$ \\
\hline In ovo & $\begin{array}{l}\text { Control }(n=22) \\
\text { Glutethimide }(6 \mathrm{mg} / \mathrm{egg})(n=16) \\
\text { Phenobarbitone }(8 \mathrm{mg} / \mathrm{egg})(n=16) \\
\text { Mephenytoin }(6 \mathrm{mg} / \mathrm{egg})(n=4)\end{array}$ & $\begin{array}{l}0.4 \pm 0.4 \\
3 \pm 6 \\
0.4 \pm 1 \\
0.6 \pm 0.03\end{array}$ & $\begin{array}{c}0.4 \pm 0.5 \\
3 \pm 10 \\
0.7 \pm 0.6 \\
0.06 \pm 0.11\end{array}$ & $\begin{array}{c}0.9 \pm 0.4 \\
238 \pm 280 \\
1.0 \pm 0.1 \\
2.0 \pm 1.6\end{array}$ & $\begin{array}{l}2.0 \pm 1.0 \\
247 \pm 283^{*} \\
2 \pm 1 \\
2.9 \pm 1.2\end{array}$ \\
\hline In culture & $\begin{array}{l}\text { Control }(n=19) \\
\text { Glutethimide }(50 \mu \mathrm{M})(n=14) \\
\text { Mephenytoin }(200 \mu \mathrm{M})(n=3)\end{array}$ & $\begin{array}{c}5 \pm 10 \\
527 \pm 341^{*} \\
95 \pm 26^{*}\end{array}$ & $\begin{array}{l}18 \pm 16 \\
67 \pm 28^{*} \\
32 \pm 11\end{array}$ & $\begin{array}{l}12 \pm 9 \\
10 \pm 13 \\
19 \pm 5\end{array}$ & $\begin{array}{l}36 \pm 26 \\
606 \pm 354^{*} \\
145 \pm 26^{*}\end{array}$ \\
\hline
\end{tabular}

Table 2. Effect of actinomycin $D$ and cycloheximide on concentration of cytochrome $P-450$, haem oxygenase activity and porphyrin accumulation produced by glutethimide and methenytoin in cultured chick-embryo hepatocytes

Cultured chick-embryo hepatocytes were treated as shown for $24 \mathrm{~h}$. Each value represents the average of two measurements, which varied by $<15 \%$ from each other for cytochrome $P-450$ and haem oxygenase.

\begin{tabular}{|c|c|c|c|c|c|}
\hline Treatment & Addition & $\begin{array}{l}\text { Cytochrome } \\
P-450 \text { (pmol } / \mathrm{mg} \\
\text { of protein) }\end{array}$ & $\begin{array}{l}\text { Haem oxygenase } \\
\text { (pmol of } \\
\text { bilirubin } / \mathrm{min} \\
\text { per } \mathrm{mg} \text { of } \\
\text { protein) }\end{array}$ & $\begin{array}{l}\text { Total porphyrin } \\
\text { (pmol/mg of } \\
\text { protein) }\end{array}$ & $\begin{array}{c}\text { Protein } \\
\text { synthesis } \\
\text { (d.p.m./min per } \\
\text { mg of protein) }\end{array}$ \\
\hline Control & $\begin{array}{l}\text { None } \\
\text { Actinomycin D }(0.78 \mu \mathrm{M}) \\
\text { Cycloheximide }(0.2 \mu \mathrm{M})\end{array}$ & $\begin{array}{l}24 \\
18 \\
20\end{array}$ & $\begin{array}{l}56 \\
63 \\
47\end{array}$ & $\begin{array}{l}29 \\
25 \\
22\end{array}$ & $\begin{array}{r}21 \\
7 \\
8\end{array}$ \\
\hline Glutethimide $(50 \mu \mathrm{M})$ & $\begin{array}{l}\text { None } \\
\text { Actinomycin D }(0.78 \mu \mathrm{M}) \\
\text { Cycloheximide }(0.2 \mu \mathrm{M})\end{array}$ & $\begin{array}{c}114 \\
11 \\
58^{*}\end{array}$ & $\begin{array}{c}100 \\
46 \\
54^{*}\end{array}$ & $\begin{array}{r}712 \\
20 \\
23\end{array}$ & $\begin{array}{r}22 \\
4 \\
10\end{array}$ \\
\hline Mephenytoin $(200 \mu \mathrm{M})$ & $\begin{array}{l}\text { None } \\
\text { Actinomycin D }(0.78 \mu \mathrm{M}) \\
\text { Cycloheximide }(0.2 \mu \mathrm{M})\end{array}$ & $\begin{array}{l}181 \\
11 \\
62^{*}\end{array}$ & $\begin{array}{r}142 \\
43 \\
50\end{array}$ & $\begin{array}{r}308 \\
19 \\
24\end{array}$ & $\begin{array}{r}20 \\
6 \\
9\end{array}$ \\
\hline
\end{tabular}

Mephenytoin and glutethimide produced similar increases of haem oxygenase activity; phenobarbitone increased haem oxygenase activity only at relatively high concentrations. In contrast, 20-methylcholanthrene had no effect on haem oxygenase activity. All four drugs increased cytochrome $P-450$ in cultured hepatocytes (Fig. $2 b$ ), although the potency of phenobarbitone was less than that of the other chemicals.

In contrast with the findings in cultured cells, in embryo liver in ovo (Fig. 2c) phenobarbitone did not detectably increase the activity of haem oxygenase. All of these compounds increased cytochrome $P-450$ in embryo liver in ovo (Fig. 2d); as in culture, phenobarbitone was a relatively weak inducer of cytochrome $P-450$.

On the basis of immunochemical cross-reactions of embryo liver microsomal proteins, glutethimide and phenobarbitone induce the same form of cytochrome $P$-450. 20-Methylcholanthrene is known to induce a different form of cytochrome $P-450$ (Sato \& Omura, 1978; Sinclair et al., 1986).
The effects of glutethimide and mephenytoin on porphyrin concentrations are shown in Table 1 . Glutethimide was the most efficacious inducer of porphyrins both in embryo liver in ovo and in cultured hepatocytes. Particularly after treatment with glutethimide there was wide variation in porphyrin accumulations among embryos and cultures, which did not correlate with either cytochrome $P-450$ concentrations or haem oxygenase activities. The most striking finding was the difference in patterns of porphyrin accumulation between embryo liver and cultured hepatocytes treated with glutethimide: uroporphyrin was the predominant porphyrin that accumulated in cultured hepatocytes, whereas protoporphyrin was the predominant porphyrin that accumulated in embryo liver in ovo. Similar differences in porphyrin accumulation were previously described (Ferioli et al., 1984). Thus the cultured hepatocytes differ from hepatocytes in ovo in response to these drugs with respect to both porphyrin accumulation and haem oxygenase induction. 
Table 3. Effects of chemicals and heavy metals on concentrations of cytochrome $P-450$ and activity of haem oxygenase in cultures of chick-embryo hepatocytes

Cultured chick hepatocytes were treated as shown for 24 h. Values are means \pm S.D. $(n=4) ;{ }^{*}$ significantly different from control $(P<0.05)$.

\begin{tabular}{|c|c|c|}
\hline Treatment & $\begin{array}{l}\text { Cytochrome } P-450 \\
\text { (pmol/mg of protein) }\end{array}$ & $\begin{array}{c}\text { Activity of haem } \\
\text { oxygenase } \\
\text { (pmol of bilirubin/min } \\
\text { per mg of protein) }\end{array}$ \\
\hline 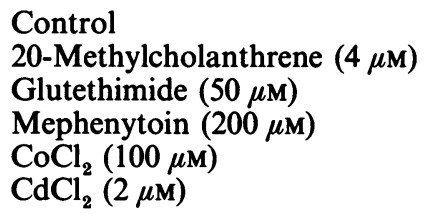 & $\begin{array}{l}24 \pm 5 \\
43 \pm 5^{*} \\
117 \pm 7^{*} \\
134 \pm 12^{*} \\
14 \pm 7 \\
24 \pm 3\end{array}$ & $\begin{array}{l}34 \pm 2 \\
45 \pm 15 \\
83 \pm 8^{*} \\
66 \pm 10^{*} \\
260 \pm 26^{*} \\
291 \pm 13^{*}\end{array}$ \\
\hline
\end{tabular}
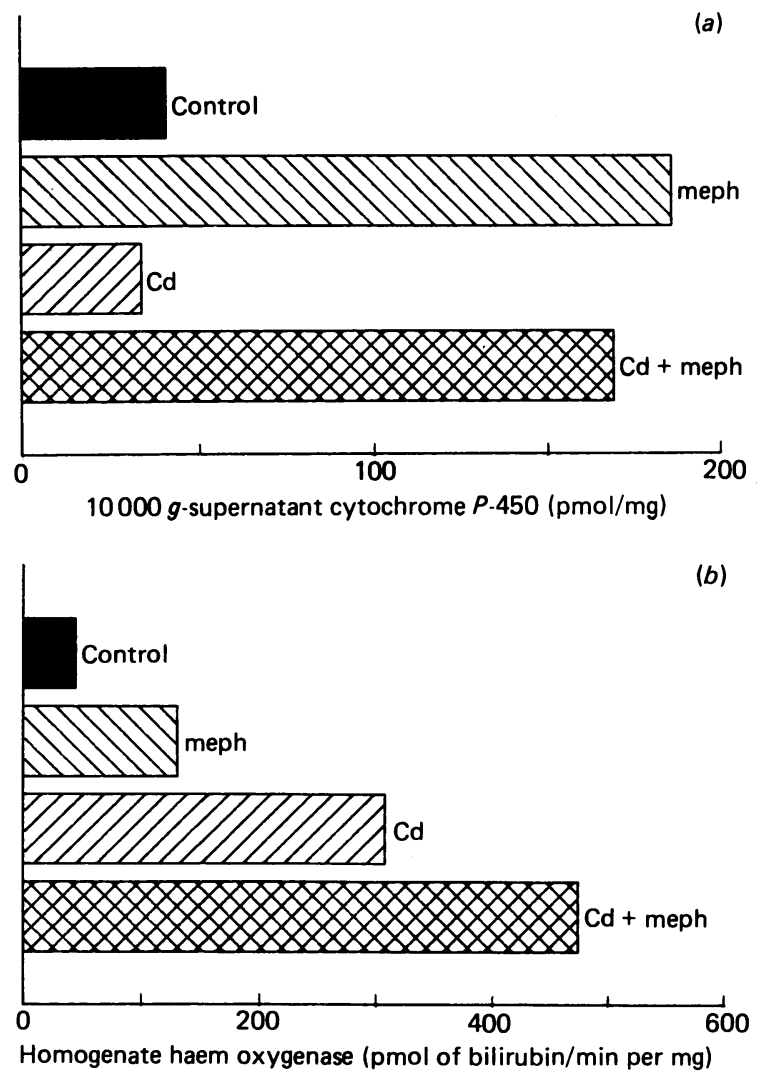

Fig. 3. Effect of cadmium on mephenytoin-mediated increases in (a) cytochrome $P-450$ and $(b)$ haem oxygenase in cultured hepatocytes

Cultured chick hepatocytes were treated for $24 \mathrm{~h}$. Final concns: mephenytoin (meph), $200 \mu \mathrm{M}$; cadmium, $2 \mu \mathrm{M}$. Results are averages of two measurements which differed from each other by $<10 \%$.

In cultured hepatocytes, cycloheximide and actinomycin blocked the increases in cytochrome $P-450$, haem oxygenase and porphyrins by glutethimide and mephenytoin (Table 2). Although protein synthesis was markedly decreased by cycloheximide and actinomycin, cytochrome $P-450$, haem oxygenase and porphyrin concentrations did not fall below control values.
A comparison of the effects of several chemicals on cytochrome $P-450$ and haem oxygenase in cultured hepatocytes is shown in Table 3. 20-Methylcholanthrene increased only cytochrome $P-450$; cobalt and cadmium increased only haem oxygenase; glutethimide and mephenytoin increased both cytochrome $P-450$ and haem oxygenase. These results suggest that cytochrome $P-450$ and haem oxygenase are independently regulated. To emphasize further the independence of cytochrome $P-450$ and haem oxygenase regulation, cultured cells were exposed to both mephenytoin and cadmium (Fig. 3). Mephenytoin-mediated induction of cytochrome $P-450$ in the presence of cadmium was similar to that of mephenytoin alone, despite a greater than 10-fold increase over control in haem oxygenase activity. Induction of haem oxygenase in the presence of both cadmium and mephenytoin appeared to be additive.

The relationship between the induction of cytochrome $P-450$ and haem oxygenase activity in cultured hepatocytes was further probed by the addition of inhibitors of haem synthesis. 4,6-Dioxoheptanoic acid is an inhibitor of ALA dehydratase (Tschudy et al., 1981), and desferrioxamine blocks conversion of protoporphyrin into haem (Shedlofsky et al., 1987). These inhibitors had little effect on porphyrin accumulation or concentrations of cytochrome $P-450$ in control cells (Figs. $4 a$ and $4 b$ ). However, in cells treated with mephenytoin, the inhibitors of haem synthesis prevented induction of both cytochrome $P-450$ and haem oxygenase by mephenytoin (Figs. $4 b$ and $4 c$ ); as expected, 4,6-dioxoheptanoic acid blocked porphyrin accumulation, whereas desferrioxamine resulted in protoporphyrin accumulation (Fig. 4a).

Exposure of control cells to $10 \mu \mathrm{M}$-haem increased concentrations of cytochrome $P-450(P<0.01)$, suggesting the presence of some apo-cytochrome $P-450$. Haem is a potent inducer of haem oxygenase, as shown with both control and mephenytoin-treated cells (Fig. $4 c$ ). The addition of haem plus 4,6-dioxoheptanoic acid or desferrioxamine fully restored the mephenytoinmediated increase in cytochrome $P-450$, implying that mephenytoin alone increased both haem synthesis and apoprotein synthesis. 4,6-Dioxoheptanoic acid and desferrioxamine had no effect on the haem-mediated induction of haem oxygenase, in either control or mephenytoin-treated cells. 

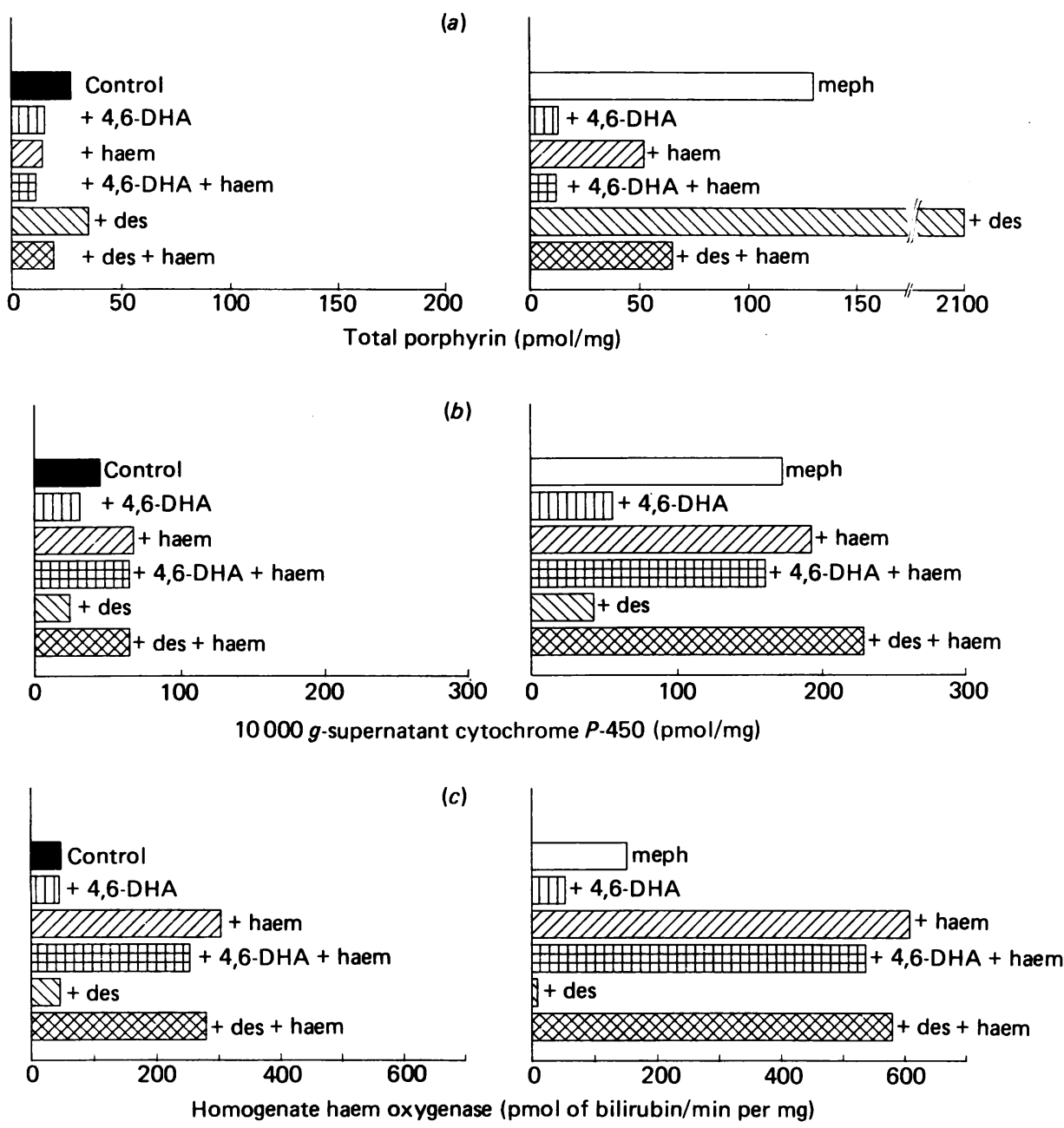

Fig. 4. Effect of 4,6-dioxoheptanoic acid, desferrioxamine, haem and mephenytoin on (a) porphyrins, (b) cytochrome $P$-450 concentrations and $(c)$ haem oxygenase activity in cultured hepatocytes

Cultured chick-embryo hepatocytes were exposed to various treatments as shown. Final concentrations were: 2 mm-4,6dioxoheptanoic acid (4,6-DHA); $10 \mu \mathrm{M}$-haemin (haem); $10 \mu \mathrm{M}$-desferrioxamine (des); $200 \mu \mathrm{M}$-mephenytoin (meph). Each bar represents the average of two measurements, which varied by $<10 \%$ of the mean.

In contrast with the major effects on drug-mediated increases in haem oxygenase, 4,6-dioxoheptanoic acid had little effect on metal induction of haem oxygenase (Fig. 5a).

\section{DISCUSSION}

A major finding of this paper is that the activity of haem oxygenase and the concentration of cytochrome $P-450$ are increased in chick-embryo hepatocytes by phenobarbitone, mephenytoin and glutethimide. These chemicals increase the same form of cytochrome $P-450$ in chick-embryo hepatocytes (Sinclair et al., 1986). Synthesis of new RNA and protein is required in order for these drug effects to occur, as shown by the inhibitions produced by actinomycin $\mathrm{D}$ and cycloheximide (Table 2 ). Induction of the apoprotein moiety of cytochrome $P$ 450 is believed secondarily to produce a partial depletion of the regulatory haem pool, and in turn to cause a derepression of ALA synthase (Granick et al., 1975; Bonkovsky, 1982). However, the possibility that induction of ALA synthase occurs by a mechanism indepen- dent of changes in a regulatory haem pool has not been excluded. The experiments with inhibitors of haem synthesis and haem (Fig. 4) indicate that phenobarbitonelike chemicals increase synthesis of both the haem and the apoprotein moieties of cytochrome $P-450$, thereby increasing concentrations of the holo-cytochrome. The experiments further suggest that induction of haem oxygenase activity by phenobarbitone-like chemicals is a secondary effect, dependent on increased haem synthesis (Lincoln \& Bonkovsky, 1987). 4,6-Dioxoheptanoic acid and desferrioxamine, both potent inhibitors of haem synthesis with different sites of action, completely prevented increases in haem oxygenase in the presence of phenobarbitone-like drugs, effects that were reversed by the addition of haem (Fig. 4). That haem is involved in these drug effects is further supported by examination of the time courses in Fig. 1, in which an increase in cytochrome $P-450$ concentrations preceded the increase in haem oxygenase activity.

Our current results also clearly show that there is a second mechanism for the induction of haem oxygenase that is not dependent on increased regulatory haem. This 

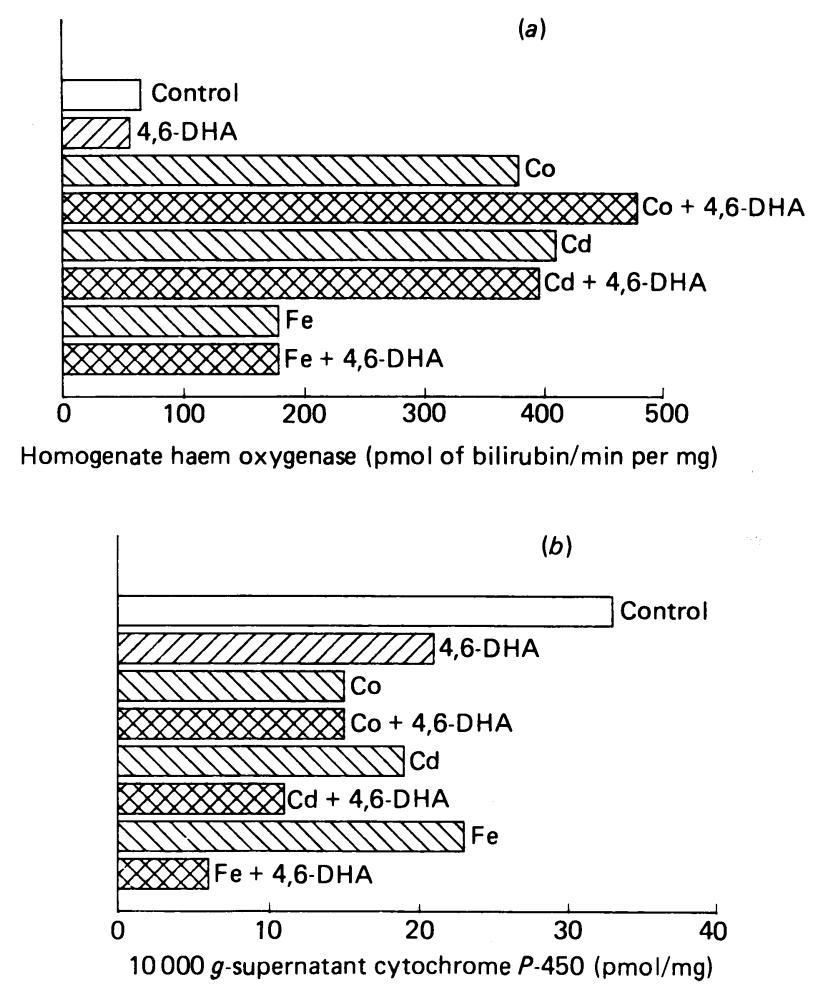

Fig. 5. Effect of heavy metals (Co, Cd, Fe) and 4,6-dioxoheptanoic acid on (a) cytochrome $P-450$ and (b) haem oxygenase in cultured hepatocytes

Cultured chick-embryo hepatocytes were exposed to various chemicals as shown, for $24 \mathrm{~h}$. Final concentrations of chemicals were: $2 \mathrm{mM}-4,6$-dioxoheptanoic acid $(4,6-$ DHA), $100 \mu \mathrm{M}-\mathrm{CoCl}_{2}, 2 \mu \mathrm{M}-\mathrm{CdCl}_{2}$, and ferric nitrilotriacetate ( $\mathrm{Fe} ; 100 \mu \mathrm{M}-\mathrm{Fe}^{3+}+200 \mu \mathrm{M}$-nitrilotriacetic acid). Each bar represents the average of two measurements which varied by $<10 \%$ from the mean.

conclusion is supported by the experiments with metals that produce marked increases in activity of haem oxygenase, with no concomitant increases, and indeed moderate decreases, in concentrations of cytochrome $P$ 450 (Fig. 5b). Furthermore, the metal induction of haem oxygenase occurred even when haem synthesis was blocked by the addition of 4,6-dioxoheptanoic acid or desferrioxamine (Fig. 5).

The observation that iron increased activity of haem oxygenase, even when haem formation was blocked by the presence of 4,6-dioxoheptanoic acid (Fig. 5a), provides evidence that iron itself, as well as its protoporphyrin chelate haem, is a proximate mediator of the induction of hepatic haem oxygenase. The greater induction of haem oxygenase activity by ferric nitrilotriacetate than by other iron salts (Sardana et al. 1982 ) is probably due to greater cellular iron uptake of the iron-nitrilotriacetate complex (Shedlofsky et al., 1983). Thus iron, acting as a heavy metal, analogous to cobalt or cadmium, increases the activity of haem oxygenase by one mechanism, whereas haem increases this activity by another mechanism. The present results in chick-embryo hepatocytes support the concept of at least two disparate mechanisms for induction of haem oxygenase, previously suggested from studies in rats (Kikuchi \& Yoshida, 1983).
Glutethimide and mephenytoin were found to increase porphyrin accumulation both in hepatocytes in ovo and in culture (Table 1). The increase in porphyrins in ovo was primarily observed for glutethimide-treated eggs and was principally protoporphyrin (Table 1 ). In cultures, all the drugs tested produced an increase in porphyrin accumulation, and the majority of this porphyrin was uro- rather than proto-porphyrin. These findings are similar to those previously described (Ferioli et al., 1984). As discussed elsewhere (Bonkovsky et al., 1987), the predominance of uroporphyrin accumulation in the cultures is probably related to an increased propensity for uroporphyrinogen to be oxidized to the corresponding porphyrin, which is not a substrate for uroporphyrinogen decarboxylase, the enzyme that converts uroporphyrinogen via stepwise decarboxylation into coproporphyrinogen. Despite porphyrin accumulation, treatment of hepatocytes with glutethimide and similar chemicals actually produced an excess of haem beyond that required for cytochrome $P-450$ induction, as shown by an apparent increase in haem saturation of tryptophan dioxygenase (B. C. Lincoln, A. Alvarado, N. Setty \& H. L. Bonkovsky, unpublished work), the ability to sustain cytochrome $P-450$ induction in the presence of elevated haem oxygenase activity (Fig. 3), and increased haem degradation (Lincoln \& Bonkovsky, 1987). The fact that haem excess occurred is evidence against the view that an increase in ALA synthesis, and thus haem synthesis, produced by glutethimide and similar drugs is related solely to increased haem demand by cytochrome $P-450$.

In conclusion, glutethimide and mephenytoin induce cytochrome $P-450$, and secondarily haem oxygenase activity owing to increased haem formation. In contrast, metal induction of haem oxygenase activity occurs independent of increased haem formation.

This work was supported by grants from N.I.H. (DK 38825 and RR00039). We thank Ms. Pat Gulliford for assistance with typing the manuscript.

\section{REFERENCES}

Abraham, N. G., Lutton, J. D., Freedman, M. L. \& Levere, R. D. (1986) Am. J. Med. Sci. 292, 81-86

Badawy, A. A.-B. \& Evans, M. (1975) Biochem. J. 150, 511-520

Badawy, A. A.-B. \& Morgan, C. J. (1980) Biochem. J. 186, 763-772

Bonkovsky, H. L. (1982) in A Textbook of Liver Disease (Zakim, D. \& Boyer, T. D., eds.), pp. 351-393, Saunders, Philadelphia

Bonkovsky, H. L., Wood, S. G., Howell, S. K., Sinclair, P. R., Lincoln, B. C., Healey, J. F. \& Sinclair, J. F. (1986) Anal. Biochem. 155, 54-64

Bonkovsky, H. L., Sinclair, P. R., Bement, W. J., Lambrecht, R. W. \& Sinclair, J. F. (1987) Ann. N.Y. Acad. Sci., in the press

Drummond, G. S., Rosenberg, D. W. \& Kappas, A. (1982) Biochem. J. 202, 59-66

Ferioli, A., Harver, C. \& de Matteis, F. (1984) Biochem. J. 224, 769-777

Grandchamp, B., Deybach, J. C., Grelier, M., deVerneuil, H. \& Nordmann, Y. (1980) Biochim. Biophys. Acta 629, 577-586

Granick, S., Sinclair, P., Sassa, S. \& Grieninger, G. (1975) J. Biol. Chem. 250, 9215-9225 
Kikuchi, G. \& Yoshida, T. (1983) Mol. Cell. Biochem. 53/54, 163-183

Lincoln, B. C. \& Bonkovsky, H. L. (1987) Fed. Proc. Fed. Am. Soc. Exp. Biol. 46, 2264

Lincoln, B., Healey, J., Sinclair, P., Frezza, J., Sinclair, J. \& Bonkovsky, H. (1986) Fed. Proc. Fed. Am. Soc. Exp. Biol. 45, 1763

Lowry, O. H., Rosebrough, N. J., Farr, A. L. \& Randall, R. J. (1951) J. Biol. Chem. 193, 265-275

Maines, M. D. \& Kappas, A. (1974) J. Biol. Chem. 250, 4171-4177

Maines, M. D. \& Kappas, A. (1977) Science 198, 1215-1221

Maines, M. D. \& Sinclair, P. (1977) J. Biol. Chem. 252, 219-223

Morgan, C. J. \& Badawy, A. A.-B. (1980) Biochem J. 186, 993-996

Omura, T. \& Sato, R. (1964) J. Biol. Chem. 239, 2370-2385

Paine, A. J. \& Legg, R. F. (1978) Biochem. Biophys. Res. Commun. 81, 672-679

Salter, M. \& Pogson, C. I. (1986) Biochem. J. 240, 259-263

Sardana, M. K. \& Drummond, G. S. (1985) Biochem. Pharmacol. 35, 473-478

Sardana, M. K., Sassa, S. \& Kappas, A. (1980) J. Biol. Chem 255, 11320-11323

Received 15 June 1987/15 September 1987; accepted 26 October 1987
Sardana, M. K., Sassa, S. \& Kappas, A. (1982) J. Biol. Chem. 257, 4806-4811

Sato, R. \& Omura, T. (1978) Cytochrome P-450, pp. 14-16, Academic Press, New York

Schacter, B. A. \& Mason, J. I. (1974) Arch. Biochem. Biophys. 160, 274-278

Shedlofsky, S. I., Sinclair, P. R., Sinclair, J. F. \& Bonkovsky, H. L. (1983) Biochem. Pharmacol. 33, 1487-1491

Shedlofsky, S. I., Bonkovsky, H. L., Swim, A. T., Sinclair, P. R., Healey, J. F. \& Robinson, J. M. (1987) Biochem. J. 248, 229-236

Sinclair, J. F., Sinclair, P. R. \& Bonkovsky, H. L. (1979) Biochem. Biophys Res. Commun. 86, 710-717

Sinclair, P., Frezza, J., Sinclair, J., Bement, J., Healey, J. \& Bonkovsky, H. (1986) Fed. Prod. Fed. Am. Soc. Exp. Biol. 45, 1663

Tenhunen, R., Marver, H. S. \& Schmid, R. (1969) J. Biol. Chem. 244, 6388-6394

Thomas, P. E., Lu, A. Y. H., Ryan, D., West, S. B. \& Kawale, K. J. (1976) J. Biol. Chem. 251, 1385-1391

Tschudy, D. P., Hess, R. A. \& Frykholm, B. C. (1981) J. Biol. Chem. 256, 9915-9923

Yoshida, T., Arakaki, M., Kumakawa, J. \& Kuroiwa, Y. (1984) J. Pharmacobio-Dyn. 7, 112-119 